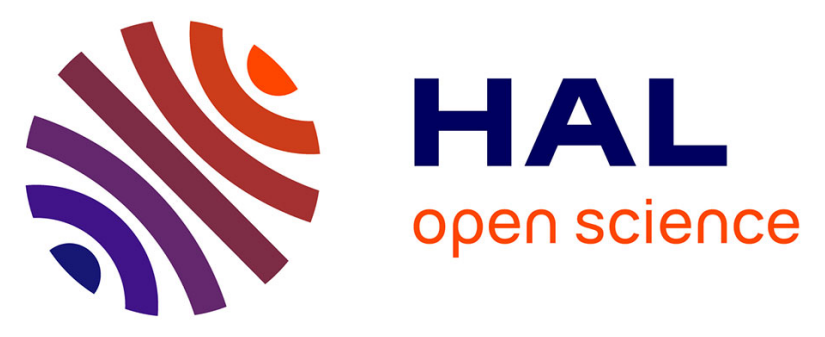

\title{
Active Control of Silicon Nanotweezers Detects Enzymatic Reaction at the Molecular Level
}

Nicolas Lafitte, Yassine Haddab, Yann Le Gorrec, Hervé Guillou, Laurent Jalabert, Dominique Collard, Hiroyuki Fujita

\section{- To cite this version:}

Nicolas Lafitte, Yassine Haddab, Yann Le Gorrec, Hervé Guillou, Laurent Jalabert, et al.. Active Control of Silicon Nanotweezers Detects Enzymatic Reaction at the Molecular Level. 17th International Conference on Solid-State Sensors, Actuators and Microsystems, TRANSDUCERS'13 \& EUROSENSORS XXVII, Jan 2013, Barcelona, Spain. pp.1077-1078. hal-00912510

\author{
HAL Id: hal-00912510 \\ https://hal.science/hal-00912510
}

Submitted on 2 Dec 2013

HAL is a multi-disciplinary open access archive for the deposit and dissemination of scientific research documents, whether they are published or not. The documents may come from teaching and research institutions in France or abroad, or from public or private research centers.
L'archive ouverte pluridisciplinaire HAL, est destinée au dépôt et à la diffusion de documents scientifiques de niveau recherche, publiés ou non, émanant des établissements d'enseignement et de recherche français ou étrangers, des laboratoires publics ou privés. 


\section{ACTIVE CONTROL OF SILICON NANOTWEEZERS DETECTS ENZYMATIC REACTION AT THE MOLECULAR LEVEL

\author{
N. Lafitte ${ }^{1,3^{*}}$, Y. Haddab ${ }^{2}$, Y. Le Gorrec ${ }^{2}$, H. Guillou ${ }^{1}$, M. Kumemura ${ }^{1,3}$, L. Jalabert ${ }^{1}$, D. Collard ${ }^{1,3}$ \\ and H. Fujita ${ }^{3}$ \\ ${ }^{1}$ LIMMS/CNRS-IIS (UMI-2820), The University of Tokyo, Tokyo, JAPAN \\ ${ }^{2}$ FEMTO-ST/UFC-ENSMM-UTBM-CNRS, Besançon, FRANCE \\ ${ }^{3}$ The University of Tokyo, Tokyo, JAPAN
}

This work achieved the control of micromachined tweezers for the enhancement of the sensing of DNA molecules and related enzymatic reactions. The mechanical stiffness of the silicon nanotweezers is decreased by feedback design and the sensitivity of the system is drastically improved.

Biological characterizations on DNA molecules have been performed monitoring the mechanical resonance frequency of the system [1]. DNA molecules are trapped by dielectrophoresis in between the nanotips of the tweezers and form a bundle of several hundreds of DNA molecules. The MEMS integrates electrostatic comb-drive actuator and capacitive sensor with sub-nanometer resolution. The in-situ real-time monitoring of the mechanical parameters allowed the characterizations of molecules trapping [2] or digestion kinetics of DNA by restriction enzymes [3].

However the resolution of the current system is limited by the resolution of the electronic circuit, while the sensitivity is limited by the mechanical design of the tweezers. In order to improve the overall system sensitivity to force gradient $(\mathrm{N} / \mathrm{m})$ characterizations, one may decrease the tweezers stiffness. Unfortunately such a design would result in a system too fragile for fabrication and experimentation. As it remains problematic to design a new all-integrated MEMS device with extremely low stiffness $(<1 \mathrm{~N} / \mathrm{m})$, we propose a new method to emulate a compliant system. Based on a model of the system, a state feedback gain is computed in order to obtain a new system with a lowered frequency of resonance with respect to the natural frequency of the tweezers (Figure 1). Theory predicts that the shift of the resonance upon molecular stiffness variations is increased for such system.

We demonstrate the enhancement by the monitoring of reactions on DNA with HindIII restriction enzymes in open-loop and in closed-loop. The feedback is implemented on a dSPACE prototyping board, carrying out the sensor signal integration and the device control generation.

After trapping of DNA molecules, the probes of the tweezers with trapped bundle are introduced into the reaction cell filled with the enzyme solution (Figure 2). Frequency response of the tweezers is continuously recorded with 50ms-time resolution using a Phase-Locked-Loop (PLL) algorithm.

Figure 3 depicts the change of the resonance frequency from the open loop driven tweezers and the closed loop system while the DNA is digested by the enzymes. During time in both situations the resonance frequency of the system decreases and the amplitude increases due to the reduction of the bundle rigidity and of the viscous losses brought by the bundle. Both curves show the same time reaction that depends on the enzymatic activity and the enzyme concentration. This time reaction is actually in adequacy with what we have previously published in [3] with a set of different enzyme concentrations. However for a same concentration, in the case of the closed-loop driven system, Figures 4 and 5 demonstrates that the variations of the resonance frequency and amplitude during the digestion and the sensitivity $\Delta \mathrm{f} / \Delta \mathrm{k}$ are larger than in open-loop.

An enhancement of the sensitivity to parameter variations was demonstrated using closed-loop control. The sensing limit is currently the detection of $30 \lambda$-DNA molecules stiffness (i.e. $1 \mathrm{mN} / \mathrm{m}$ ) in liquid (Figure 6). Approaching the sensitivity of one DNA molecule clears the way for biological experiments on single molecule with MEMS tweezers, like with complex systems such as AFM or optical tweezers. This novel method opens up the possibility to achieve this objective and can be applied to other MEMS actuators/sensors where low stiffness is required.

\section{Word Count: 566}

\section{REFERENCES:}

[1] C. Yamahata et al., J. Microelectromech. Syst., vol. 17(3), pp. 623-631, 2008.

[2] N. Lafitte et al., Proc. of MicroTAS'10, Groningen, Nov. 2010, pp. 1865-1868.

[3] M. Kumemura et al., Proc. of IEEE MEMS'10, Hong-Kong, Jan. 2010, pp. 915-918. 


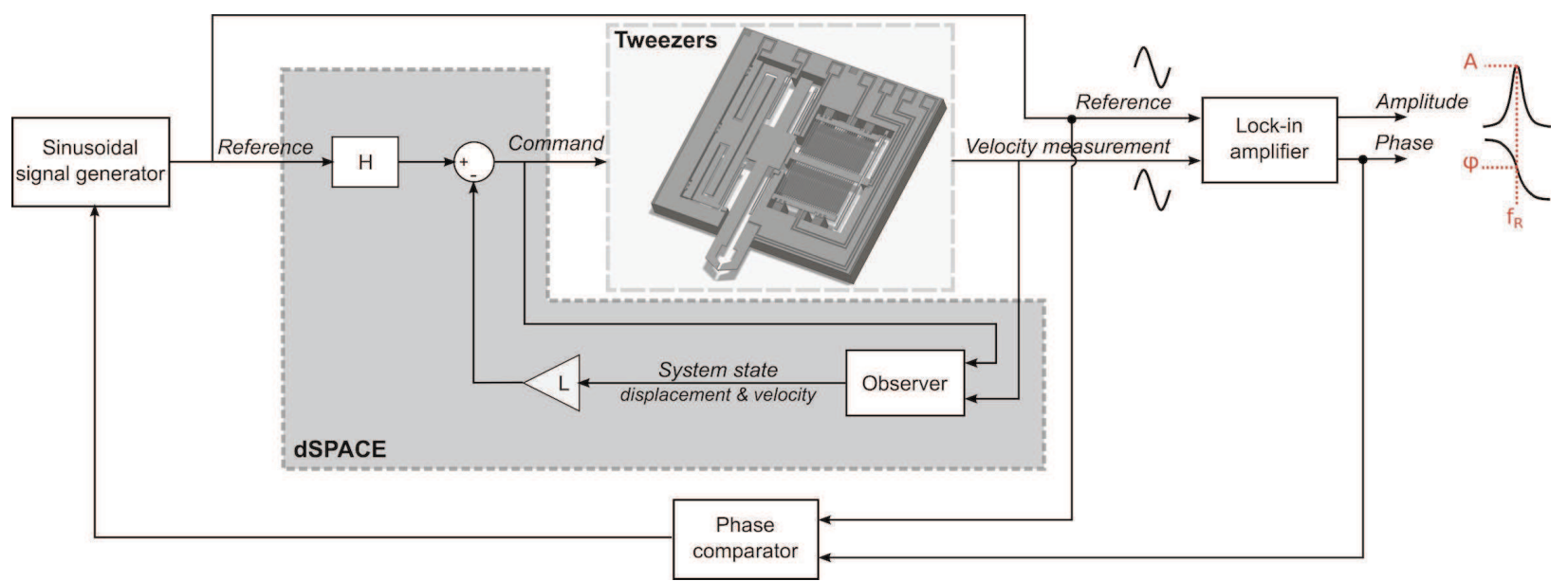

Figure 1. Feedback control and PLL schematic. Silicon nanotweezers (SNT) integrate electrostatic comb-drive actuator and capacitive sensor allowing feedback implementation. State feedback implementation requires in addition the design of an observer for system state reconstruction.

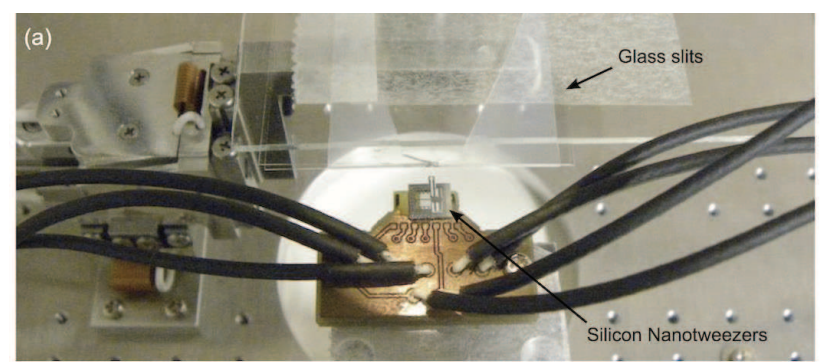

(b)

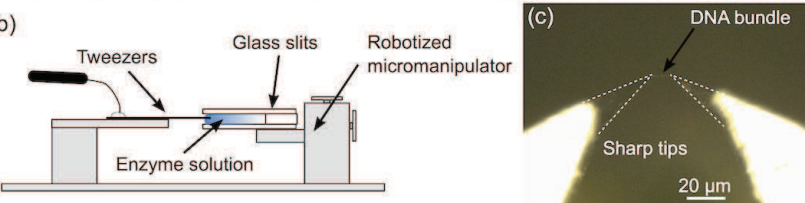

Figure 2: Experimental set-up for the monitoring of enzymatic reaction on DNA. (a) Photo top-view of the SNT and the fluidic. (b) Scheme side-view of the immersion of the tweezers tips into enzyme solution. (c) Microscopic image of the tips and the trapped DNA bundle before digestion by the enzymes.

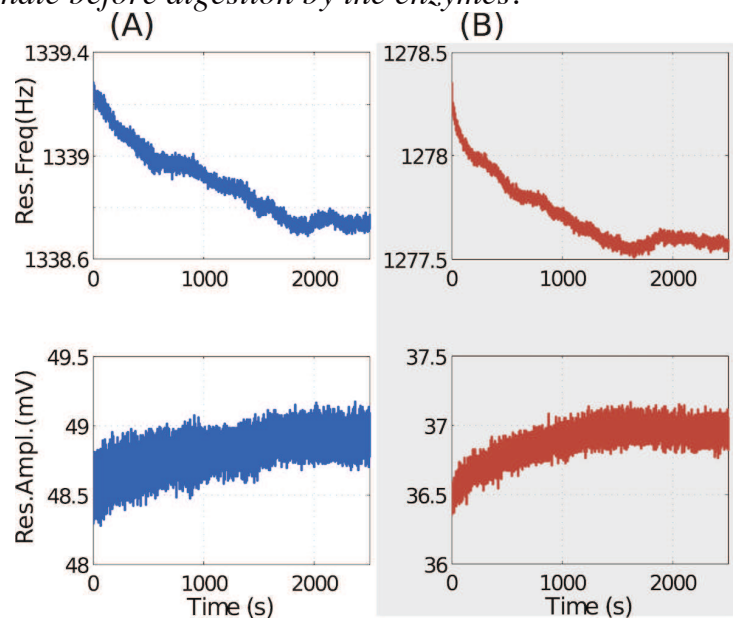

Figure 3: Real-time monitoring of reactions of HindIII restriction enzymes on $\lambda$-DNA molecules. Experiments have been performed with (A) open-loop driven tweezers and $(B)$ implementing the closed-loop control.

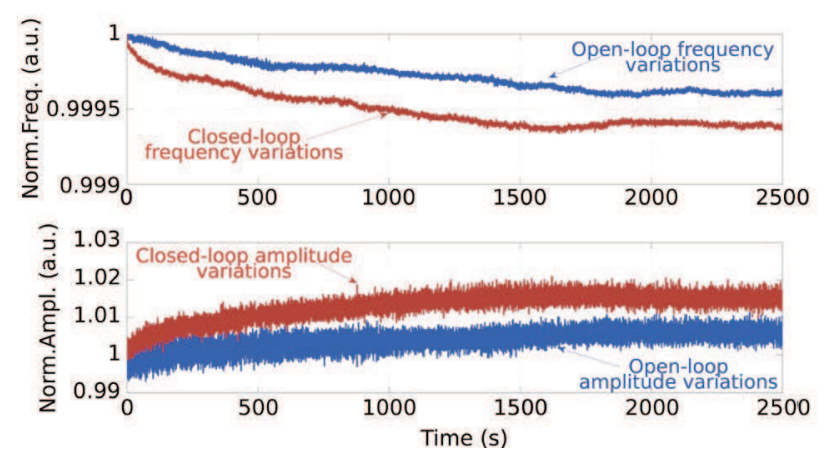

Figure 4: Comparison of the performances of the openloop driven system and the closed-loop system. Resonance frequency and amplitude have been normalized with their model values.

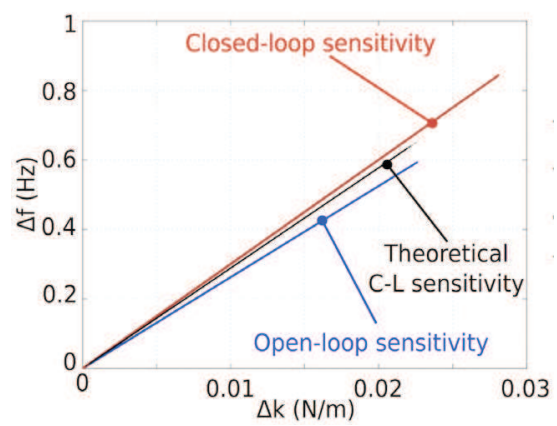

Figure 5: Sensitivity $\Delta f / \Delta k$ comparison between openloop system and closed-loop system. The closed-loop curve shows a larger sensitivity and a better resolution.

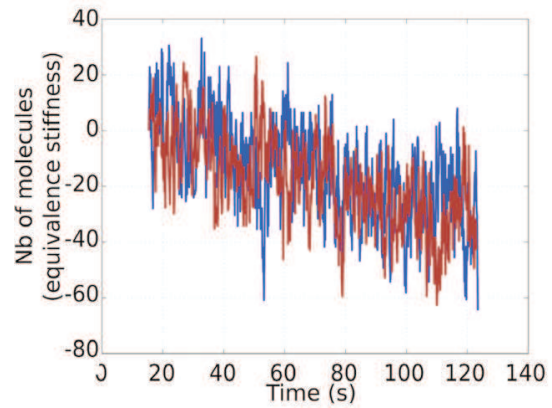

Figure 6: Noise comparison of the open-loop and the closed-loop systems. The SNR is not degraded. 